\title{
Soll Organisms Associated to THE WeEd Suppressant Crotalaria juncea (FABACEAE) AND ITS IMPORTANCE AS A REFUGE FOR NATURAL ENEMIES ${ }^{1}$
}

\author{
Organismos de Solo Associados à Supressora de Plantas Daninhas Crotalaria juncea \\ (Fabaceae) e sua Importância como Refúgio para Inimigos Naturais
}
TAVARES, W.S. ${ }^{2}$, CRUZ, I. ${ }^{3}$, SILVA, R.B. ${ }^{4}$, FIGUEIREDO, M.L.C. ${ }^{3}$, RAMALHO, F.S. ${ }^{5}$, SERRÃO, J.E. ${ }^{6}$ and ZANUNCIO, J.C. ${ }^{7}$

\begin{abstract}
Soil organisms play an important role in organic crops of Crotalariajuncea (Fabaceae) and are associated with the natural conservation of the environment. The present study was aimed to investigate the population of soil organisms in the organic culture of $C$. juncea, as well as its importance as a refuge for natural enemies. Dalbulus maidis (Hemiptera: Cicadellidae), Diabrotica sp. (Coleoptera: Chrysomelidae), Doru luteipes (Dermaptera: Forficulidae), Gryllus assimilis (Orthoptera: Gryllidae), Lagria villosa (Coleoptera: Lagriidae), Melanotus sp. (Coleoptera: Elateridae), Meloidogyne incognita (Tylenchida: Heteroderidae), Nephila clavipes (Araneae: Nephilidae), Orius insidiosus (Hemiptera: Anthocoridae), Pheidole sp. (Hymenoptera: Myrmicidae), Phyllophaga sp. (Coleoptera: Scarabeidae), Procornitermes sp. (Isoptera: Termitidae), Solenopsis sp. (Hymenoptera: Formicidae), and Utetheisa ornatrix (Lepidoptera: Arctiidae) were identified in C. juncea. The organisms that were found during a 3-month period in 144 trenches in C. juncea were pest species (84.47\%) and natural enemies $(15.53 \%)$ as well. Natural enemies had an average of 11.89 individuals per $1.08 \mathrm{~m}^{3}$ of soil cultivated with $C$. juncea. The abundance of organisms in the pod stage $(5.49 \%)$ of $C$. juncea was lower than that in the vegetative (83.50\%) and flowering (11.01\%) stages. Crotalariajuncea plants can be used as part of a crop system for Integrated Pest Management.
\end{abstract}

Keywords: Crotalaria juncea, natural enemies, organic agriculture, pests, soil organisms, sun hemp.

\begin{abstract}
RESUMO - Organismos de solo desempenham um importante papel em cultivos orgânicos de Crotalaria juncea (Fabaceae) e estão associados com a conservação natural do ambiente. O presente estudo teve como objetivo investigar a população de organismos de solo no cultivo orgânico de C. juncea, bem como sua importância como um refúgio para inimigos naturais. Dalbulus maidis (Hemiptera: Cicadellidae), Diabrotica sp. (Coleoptera: Chrysomelidae), Doru luteipes (Dermaptera: Forficulidae), Gryllus assimilis (Orthoptera: Gryllidae), Lagria villosa (Coleoptera: Lagriidae), Melanotus sp. (Coleoptera: Elateridae), Meloidogyne incognita (Tylenchida: Heteroderidae), Nephila clavipes (Araneae: Nephilidae), Orius insidiosus (Hemiptera: Anthocoridae), Pheidole sp. (Hymenoptera: Myrmicidae), Phyllophaga sp. (Coleoptera: Scarabeidae), Procornitermes sp. (Isoptera: Termitidae), Solenopsis sp. (Hymenoptera: Formicidae) e Utetheisa ornatrix (Lepidoptera: Arctiidae) foram identificados em C. juncea. Os organismos que foram encontrados durante um periodo de três meses em 144 trincheiras em $\boldsymbol{C}$. juncea foram as espécies de pragas (84, 47\%) e inimigos naturais (15,53\%). Inimigos naturais tiveram uma média de 11,89 individuos por 1, $08 \mathrm{~m}^{3}$ de solo cultivado com C. juncea. A abundância de organismos na fase de vagem (5,49\%) de C. juncea foi menor do que nas fases vegetativa (83,50\%) e floração (11,01\%). Plantas de C. juncea podem ser usadas como parte de um sistema de cultivo para o Manejo Integrado de Pragas.
\end{abstract}

Palavras-chave: Crotalaria juncea, inimigos naturais, agricultura orgânica, pragas, organismos do solo, crotalária.

Recebido para publicação em 8.9.2010 e aprovado em 31.3.2011.

2 Programa de Pós-Graduação em Fitotecnia, Universidade Federal de Viçosa - DFT/UFV, 36570-000 Viçosa, Minas Gerais State, Brazil,<wagner.tavares@ufv.br>; ${ }^{3}$ Embrapa Milho e Sorgo, Rodovia MG 424, Km 65, Caixa Postal 151, 35701-970 Sete Lagoas, Minas Gerais State, Brazil, <ivancruz@cnpms.embrapa.br>; ${ }^{4}$ Programa de Pós-Graduação em Ecologia e Recursos Naturais, Universidade Federal de São Carlos, 13565-905 São Carlos, São Paulo State, Brazil, <rafaelentomologia@yahoo.com.br>; ${ }^{5}$ Unidade de Controle Biológico, EMBRAPAAlgodão, Av. Osvaldo Cruz, 1143, 58107-720 Campina Grande, Paraíba, Brazil, ramalhohvv@globo.com; ${ }^{6}$ Dep. de Biologia Geral, DBG/UFV, <jeserrao@ufv.br>; 7 Dep. de BiologiaAnimal, DBA/UFV, <zanuncio@ufv.br>.

Planta Daninha, Viçosa-MG, v. 29, n. 3, p. 473-479, 2011 


\section{INTRODUCTION}

Green manure of legumes is a beneficial cultural practice to production systems (Silva et al., 1998). Mulching of Crotalaria juncea (Fabaceae) can improve soil structure, reduce soil erosion, and increase levels of soil organic matter and nutrients (Sharma et al., 2010). Seed germination and the amount of weed dry matter were reduced in soil covered with mulching of $C$. juncea due to increased shading and release of allelochemical substances (Queiroz et al., 2010). These substances repel nematodes, but some of these species were attracted to the roots of C. juncea (Wang et al., 2002; Chellemi, 2006). The mortality of pupae of Elasmopalpus lignosellus (Lepidoptera: Pyralidae) was higher in soil covered with mulching of $C$. juncea due to the release of allelochemical substances, humidity, and pathogenic microorganisms in the soil (Gill et al., 2010). However, some species of beetle pests can adapt themselves and survive in this crop mulching thanks to their increased resistance to soil edaphic factors (Santos et al., 2008).

Crotalaria juncea plants can be used in cropping systems to attract or repel pests, natural enemies, and other organisms (Santos et al., 2008). Other Fabaceae, including Acacia caven, Centrosema pubescens, and Stizolobium cinereum are important as refuges for natural enemies such as Araneae, Coccinellidae, Eulophidae, Heteroptera, Hymenoptera, Pteromalidae, and Trichogrammatidae (Rojas-Rousse, 2006; Silva et al., 2007). The architecture of the stems and dense cultures of $C$. juncea favored by increased humidity and lower temperature, providing areas of refuge and shelter for parasitoids and predators, besides beneficial mites and nematodes in soil (McSorley et al., 2009). A greater number of Chrysoperla externa (Neuroptera: Chrysopidae) and higher levels of bee pollination were observed during the flowering period of C. juncea, because its yellow flowers had large amounts of pollen and gave off an attractive smell (Venzon et al., 2006). Natural enemies associated with $C$. juncea migrated to agricultural crops when the plants were grown in systems of rotation or succession (Gill et al., 2010).

Planta Daninha, Viçosa-MG, v. 29, n. 3, p. 473-479, 2011
Crotalaria juncea cultures play a significant role in Integrated Pest Management (IPM) programs in weeds and crops (McSorley et al., 2008a). Weeds can be damaged by defoliators associated with $C$. juncea, which affects organic agriculture where the use of synthetic pesticides is forbidden (Gill et al., 2010). Moreover, defoliators of Phyllophaga cuyabana (Coleoptera: Melolonthidae) would rather feed on $C$. juncea than on crops (Oliveira \& Garcia, 2003; Oliveira et al., 2007). Crotalaria juncea plants increased moisture and reduced soil temperatures after the incorporation of this green manure and decaying vegetal material released allelochemical substances, attracting soil pests and repelling air natural enemies (Venette et al., 1997; McSorley et al., 2006). Soil organisms attracted by $C$. juncea cultures are little known. However, due to their relevance they are being studied.

This study was aimed to record edaphic macroinvertebrates associated to the weed suppressant species $C$. juncea and to determine its role as a refuge for natural enemies.

\section{MATERIAL AND METHODS}

The research was carried out from December 2006 to April 2007 in experimental fields and in the laboratory of the National Research Center of Corn and Sorghum (CNPMS) of the Brazilian Agricultural Research Corporation in Sete Lagoas, Minas

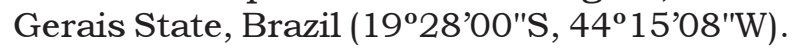
This region is characterized as semi-humid. Its predominant crop is sun hemp followed by maize. Soil chemical analyses from zero to $20 \mathrm{~cm}$ were $\mathrm{pH}\left(\mathrm{H}_{2} \mathrm{O}\right)=5.8, \mathrm{H}+\mathrm{Al}^{+3}=5.6, \mathrm{Al}^{+3}=$ $0.0, \mathrm{Ca}^{+2}=2.71, \mathrm{Mg}^{+2}=0.51, \mathrm{SB}=3.43$ and CTC $=9.03 \mathrm{cmolc} \mathrm{dm}^{-3} ; \mathrm{K}=84$ and $\mathrm{P}=$ $17 \mathrm{mg} \mathrm{dm}^{-3}$; M.O. $=3.94 \mathrm{dag} \mathrm{kg}^{-1}$, and $\mathrm{V}=38$ and SatAl $=0$.

Insects, nematodes, and spiders in the soil were extracted in a $C$. juncea stand (1.0 ha) isolated that was cultivated in December 2006 with Dystrophic Red Yellow Latosol-type soil. This stand was divided into six plots of $200 \mathrm{~m}^{2}$ each one (20 m long and $10 \mathrm{~m}$ wide) with poles. These plots were equally spaced around the stand. Two trenches $\left(0.15 \times 0.15 \mathrm{~m}^{2}\right.$ to $1.0 \mathrm{~m}$ deep) were marked and dug by plot in each sample (three samplings weekly) and the soil 
on each one was placed in plastic bags with a maximum capacity of $20 \mathrm{~kg}$ and taken to the laboratory where it was dumped on a bench. Soil organisms were extracted with forceps and brush and screened in acrylic tubes with alcohol 70\%. Root knot nematodes were not collected in C. juncea roots and plants maintained after the samplings. The collection period was from 08:00 to 12:00.

The sampling of soil organisms began when the plants were approximately 10 day old and continued weekly until $C$. juncea presented pods. Weeding was performed on a weekly basis to eliminate weeds. The sun hemp plants were in the vegetative, flowering, or pod stages during sampling. Each one of these sampling was observed in the 12 trenches (two per plot), total of $0.27 \mathrm{~m}^{3}$ of soil per week or $1.08 \mathrm{~m}^{3}$ of soil per month. Larvae of Diabrotica sp. (Coleoptera: Chrysomelidae), Melanotus sp. (Coleoptera: Elateridae) and Phyllophaga sp. (Coleoptera: Scarabeidae) and caterpillars of Utetheisa ornatrix (Lepidoptera: Arctiidae) were taken to the laboratory and maintained up to the adult stage for identification.

Randomized block design, with six replications was used; each plot consisted of 24 trenches. The foraging activity of ants was expressed as frequency (\%) in the trenches dug in the plots, to avoid overestimation of abundance of species with high recruitment capacity close to the nest (Soares et al., 1998). The abundance of other organisms was evaluated. Data were transformed into $\sqrt{ } \mathrm{X}+1$ and submitted to an analysis of variance (ANOVA), with split plots; plots were represented by trenches and subplots by the phenological stages of C. juncea, using the MSTAT-C, version 2.1 software (Supplier: CNPMS) (Russel, 1989).

\section{RESULTS AND DISCUSSION}

Fourteen species were identified in C. juncea: Dalbulus maidis (Hemiptera: Cicadellidae), Diabrotica sp., Doru luteipes (Dermaptera: Forficulidae), Gryllus assimilis (Orthoptera: Gryllidae), Lagria villosa (Coleoptera: Lagriidae), Melanotus sp., Meloidogyne incognita (Tylenchida: Heteroderidae), Nephila clavipes (Araneae: Nephilidae), Orius insidiosus (Hemiptera:
Anthocoridae), Pheidole sp. (Hymenoptera: Myrmicidae), Phyllophaga sp., Procornitermes sp. (Isoptera: Termitidae), Solenopsis sp. (Hymenoptera: Formicidae), U. ornatrix. These insects were found in the adult $(78.37 \%)$ or larva $(21.63 \%)$ stages in this culture, but Phyllophaga sp. was found in both the larval and adult stages (Table 1). The higher number of species of the order Coleoptera in the soil of C. juncea confirms that these are the most abundant species in soil with green manure Cajanus cajan (Fabaceae), C. juncea, S. cinereum, and Stylosanthes guianensis (Fabaceae) (Oliveira $\&$ Garcia, 2003; Oliveira et al., 2007; Santos et al., 2008).

Procornitermes sp. (100.72 \pm 15.20$)$, $M$. incognita (19.27 \pm 2.47$)$, Diabrotica sp. (17.58 \pm 2.35$)$, O. insidiosus (16.25 \pm 2.91$)$, and Phyllophaga sp. (12.46 \pm 1.46$)$ were abundant in the vegetative stage of C. juncea; O. insidiosus (11.50 \pm 2.59 ), Procornitermes sp. (3.29 \pm 0.27$)$, Phyllophaga sp. (2.27 \pm 0.18$)$, $U$. ornatrix $(2.11 \pm 0.20)$, and Diabrotica sp. $(2.01 \pm 0.20)$ in the flowering stage; and $O$. insidiosus (3.31 \pm 0.33$)$, Procornitermes sp. (3.09 \pm 0.27$)$, and Diabrotica sp. $(2.40 \pm 0.20)$ in the pods stage of this culture. Doru luteipes, $N$. clavipes, and $O$. insidiosus were the most common natural enemies found in C. juncea, while the most common pests were Diabrotica sp., M. incognita, Phyllophaga sp., and Procornitermes sp. The organisms found over a 3-month period in 144 trenches in C. juncea were pest species $(84.47 \%)$ and natural enemies (15.53\%). Natural enemies had an average of 11.89 individuals per $1.08 \mathrm{~m}^{3}$ of soil cultivated with $C$. juncea. The abundance of organisms in the pod stage $(5.49 \%)$ of $C$. juncea was lower than that in the vegetative $(83.50 \%)$ and flowering $(11.01 \%)$ stages (Table 1). Insect pests had lower populations during the flowering and pod stages of $C$. juncea than did those in Phaseolus lunatus (Fabaceae), suggesting toxic effects of nectar from flowers of the first plant of these species (Kost \& Heil, 2005). Organisms as Diabrotica sp. (Jones \& Coppedge, 2000, Jackson \& Harrison, 2008), N. clavipes (Ferro et al., 2006), O. insidiosus (Erlandson \& Obrycki, 2010), Phyllophaga spp. (Lewis et al., 2003), and U. ornatrix (Iyengar \& Eisner, 2002; Guimarães et al., 2006) were abundant in C. juncea and/or other Fabaceae. 
Table 1 - Number of individuals (means \pm standard error of mean) as function of the stage of Crotalaria juncea (Fabaceae) plants $\underline{1}^{\prime}$

\begin{tabular}{|c|c|c|c|}
\hline Taxons & Vegetative & Flowering & Pods \\
\hline & \multicolumn{3}{|c|}{ Herbivores } \\
\hline Coleoptera Chrysomelidae adults & & & \\
\hline $\begin{array}{l}\text { Diabrotica } \mathrm{sp} . \\
\text { Diabrotica } \mathrm{sp} . / 1.08 \mathrm{~m}^{3} \text { soil }\end{array}$ & $\begin{array}{r}17.58 \pm 2.35 \mathrm{a} \\
5.86 \pm 0.78 \mathrm{a}\end{array}$ & $\begin{array}{l}2.01 \pm 0.20 \mathrm{~b} \\
0.67 \pm 0.06 \mathrm{~b}\end{array}$ & $\begin{array}{l}2.40 \pm 0.20 \mathrm{~b} \\
0.80 \pm 0.06 \mathrm{~b}\end{array}$ \\
\hline \multicolumn{4}{|l|}{ Coleoptera Elateridae adults } \\
\hline $\begin{array}{l}\text { Melanotus sp. } \\
\text { Melanotus } \mathrm{sp} . / 1.08 \mathrm{~m}^{3} \text { soil }\end{array}$ & $\begin{array}{l}9.07 \pm 0.94 \mathrm{a} \\
3.02 \pm 0.31 \mathrm{a}\end{array}$ & $\begin{array}{l}1.26 \pm 0.09 \mathrm{~b} \\
0.42 \pm 0.03 \mathrm{~b}\end{array}$ & $\begin{array}{l}0.00 \pm 0.00 \mathrm{~b} \\
0.00 \pm 0.00 \mathrm{~b}\end{array}$ \\
\hline \multicolumn{4}{|l|}{ Coleoptera Lagriidae adults } \\
\hline $\begin{array}{l}\text { Lagria vilosa } \\
\text { Lagria vilosa } / 1.08 \mathrm{~m}^{3} \text { soil }\end{array}$ & $\begin{array}{l}1.22 \pm 0.09 \mathrm{a} \\
0.40 \pm 0.03 \mathrm{a}\end{array}$ & $\begin{array}{l}0.00 \pm 0.00 \mathrm{a} \\
0.00 \pm 0.00 \mathrm{a}\end{array}$ & $\begin{array}{l}0.00 \pm 0.00 \mathrm{a} \\
0.00 \pm 0.00 \mathrm{a}\end{array}$ \\
\hline \multicolumn{4}{|l|}{ Coleoptera Scarabeidae adults } \\
\hline $\begin{array}{l}\text { Phyllophaga } \mathrm{sp} . \\
\text { Phyllophaga } \mathrm{sp} . / 1.08 \mathrm{~m}^{3} \text { soil }\end{array}$ & $\begin{array}{l}6.07 \pm 0.74 \mathrm{a} \\
2.02 \pm 0.24 \mathrm{a}\end{array}$ & $\begin{array}{l}2.27 \pm 0.18 b \\
0.75 \pm 0.06 b\end{array}$ & $\begin{array}{l}1.41 \pm 0.09 \mathrm{~b} \\
0.47 \pm 0.03 \mathrm{~b}\end{array}$ \\
\hline \multicolumn{4}{|l|}{ Hemiptera Cicadellidae adults } \\
\hline $\begin{array}{l}\text { Dalbulus maidis } \\
\text { Dalbulus maidis } / 1.08 \mathrm{~m}^{3} \text { soil }\end{array}$ & $\begin{array}{l}2.11 \pm 0.18 \mathrm{a} \\
0.70 \pm 0.06 \mathrm{a}\end{array}$ & $\begin{array}{l}1.42 \pm 0.09 \mathrm{a} \\
0.47 \pm 0.03 \mathrm{a}\end{array}$ & $\begin{array}{l}0.00 \pm 0.00 \mathrm{a} \\
0.00 \pm 0.00 \mathrm{a}\end{array}$ \\
\hline \multicolumn{4}{|l|}{ Isoptera Termitidae adults } \\
\hline $\begin{array}{l}\text { Procornitermes } \mathrm{sp} . \\
\text { Procornitermes } \mathrm{sp} . / 1.08 \mathrm{~m}^{3} \text { soil }\end{array}$ & $\begin{aligned} 100.72 & \pm 15.20 \mathrm{a} \\
33.57 & \pm 5.06 \mathrm{a}\end{aligned}$ & $\begin{array}{l}3.29 \pm 0.27 \mathrm{~b} \\
1.09 \pm 0.09 \mathrm{~b}\end{array}$ & $\begin{array}{l}3.09 \pm 0.27 \mathrm{~b} \\
1.03 \pm 0.09 \mathrm{~b}\end{array}$ \\
\hline \multicolumn{4}{|l|}{ Lepidoptera Arctiidae adults } \\
\hline $\begin{array}{l}\text { Utetheisa ornatrix } \\
\text { Utetheisa ornatrix } / 1.08 \mathrm{~m}^{3} \text { soil }\end{array}$ & $\begin{array}{l}1.42 \pm 0.09 \mathrm{a} \\
0.47 \pm 0.03 \mathrm{a}\end{array}$ & $\begin{array}{l}2.11 \pm 0.20 \mathrm{a} \\
0.70 \pm 0.06 \mathrm{a}\end{array}$ & $\begin{array}{l}1.39 \pm 0.09 \mathrm{a} \\
0.46 \pm 0.03 \mathrm{a}\end{array}$ \\
\hline \multicolumn{4}{|l|}{ Orthoptera Gryllidae adults } \\
\hline $\begin{array}{l}\text { Gryllus assimilis } \\
\text { Gryllus assimilis } / 1.08 \mathrm{~m}^{3} \text { soil }\end{array}$ & $\begin{array}{l}2.52 \pm 0.18 \mathrm{a} \\
0.84 \pm 0.06 \mathrm{a}\end{array}$ & $\begin{array}{l}0.00 \pm 0.00 \mathrm{a} \\
0.00 \pm 0.00 \mathrm{a}\end{array}$ & $\begin{array}{l}0.00 \pm 0.00 \mathrm{a} \\
0.00 \pm 0.00 \mathrm{a}\end{array}$ \\
\hline \multicolumn{4}{|l|}{ Tylenchida Heteroderidae adults } \\
\hline $\begin{array}{l}\text { Meloidogyne incognita } \\
\text { Nematodes } / 1.08 \mathrm{~m}^{3} \text { soil }\end{array}$ & $\begin{array}{r}19.27 \pm 2.47 \mathrm{a} \\
6.42 \pm 0.82 \mathrm{a} \\
\end{array}$ & $\begin{array}{l}0.00 \pm 0.00 \mathrm{~b} \\
0.00 \pm 0.00 \mathrm{~b}\end{array}$ & $\begin{array}{l}0.00 \pm 0.00 \mathrm{~b} \\
0.00 \pm 0.00 \mathrm{~b}\end{array}$ \\
\hline \multicolumn{4}{|l|}{ Coleoptera Scarabeidae larvae } \\
\hline $\begin{array}{l}\text { Phyllophaga } \mathrm{sp} . \\
\text { Phyllophaga } \mathrm{sp} . / 1.08 \mathrm{~m}^{3} \text { soil } \\
\text { Total Herbivores } \\
\text { Herbivores/1.08 } \mathrm{m}^{3} \text { soil }^{2 /}\end{array}$ & $\begin{array}{c}12.46 \pm 1.46 \mathrm{a} \\
4.15 \pm 0.48 \mathrm{a} \\
172.44 \pm 23.70 \mathrm{a} \\
57.48 \pm 7.90 \mathrm{a} \\
\end{array}$ & $\begin{array}{r}0.00 \pm 0.00 \mathrm{~b} \\
0.00 \pm 0.00 \mathrm{~b} \\
12.36 \pm 1.03 \mathrm{~b} \\
4.12 \pm 0.34 \mathrm{~b} \\
\end{array}$ & $\begin{array}{l}0.00 \pm 0.00 \mathrm{~b} \\
0.00 \pm 0.00 \mathrm{~b} \\
8.29 \pm 0.65 \mathrm{~b} \\
2.76 \pm 0.21 \mathrm{~b}\end{array}$ \\
\hline Herbivores $/ 1.08 \mathrm{~m}^{3}$ soil $^{2 /}$ & \multicolumn{3}{|c|}{ Predators } \\
\hline \multicolumn{4}{|l|}{ Araneae Nephilidae adults } \\
\hline $\begin{array}{l}\text { Nephila clavipes } \\
\text { Nephila clavipes } / 1.08 \mathrm{~m}^{3} \text { soil }\end{array}$ & $\begin{array}{l}2.12 \pm 0.20 \mathrm{a} \\
0.70 \pm 0.06 \mathrm{a}\end{array}$ & $\begin{array}{l}0.00 \pm 0.00 \mathrm{a} \\
0.00 \pm 0.00 \mathrm{a}\end{array}$ & $\begin{array}{l}0.00 \pm 0.00 \mathrm{a} \\
0.00 \pm 0.00 \mathrm{a}\end{array}$ \\
\hline \multicolumn{4}{|l|}{ Dermaptera Forficulidae adults } \\
\hline $\begin{array}{l}\text { Doru luteipes } \\
\text { Doru luteipes } / 1.08 \mathrm{~m}^{3} \text { soil }\end{array}$ & $\begin{array}{l}1.08 \pm 0.09 \mathrm{a} \\
0.36 \pm 0.03 \mathrm{a}\end{array}$ & $\begin{array}{l}1.42 \pm 0.09 \mathrm{a} \\
0.47 \pm 0.03 \mathrm{a}\end{array}$ & $\begin{array}{l}0.00 \pm 0.00 \mathrm{a} \\
0.00 \pm 0.00 \mathrm{a}\end{array}$ \\
\hline \multicolumn{4}{|l|}{ Hemiptera Anthocoridae adults } \\
\hline $\begin{array}{l}\text { Orius insidiosus } \\
\text { Orius insidiosus } / 1.08 \mathrm{~m}^{3} \text { soil } \\
\text { Total Predators } \\
\text { Predators } / 1.08 \mathrm{~m}^{3} \text { soil }^{3 /}\end{array}$ & $\begin{array}{r}16.25 \pm 2.91 \mathrm{a} \\
5.41 \pm 0.97 \mathrm{a} \\
19.45 \pm 3.20 \mathrm{a} \\
6.48 \pm 1.06 \mathrm{a} \\
\end{array}$ & $\begin{array}{c}11.50 \pm 2.59 \mathrm{a} \\
3.83 \pm 0.86 \mathrm{~b} \\
12.92 \pm 2.68 \mathrm{a} \\
4.30 \pm 0.89 \mathrm{a} \\
\end{array}$ & $\begin{array}{l}3.31 \pm 0.33 \mathrm{~b} \\
1.10 \pm 0.11 \mathrm{~b} \\
3.31 \pm 0.33 \mathrm{~b} \\
1.10 \pm 0.11 \mathrm{~b}\end{array}$ \\
\hline Predators $/ 1.08 \mathrm{~m}^{3} \mathrm{soil}^{3 /}$ & \multicolumn{3}{|c|}{ Ants } \\
\hline \multicolumn{4}{|l|}{ Hymenoptera Formicidae } \\
\hline \multicolumn{4}{|l|}{ Pheidole sp. and Solenopsis sp. } \\
\hline Frequency $(\%)^{4 /}$ & $16.40 \pm 1.75 \mathrm{a}$ & $0.00 \pm 0.00 \mathrm{~b}$ & $0.00 \pm 0.00 \mathrm{~b}$ \\
\hline
\end{tabular}

1/ Data transformed in $\sqrt{\mathrm{X}}+1$ before statistical analyses. ${ }^{1 /}$ Means followed by the same letter per line do not differ by the $\mathrm{t}$ test (p $>0.05$ )

2/ Sum of densities of D. maidis, Diabrotica sp., G. assimilis, L. vilosa, Melanotus sp., M. incognita, Phyllophaga sp., Procornitermes sp., and U. ornatrix. ${ }^{3 /}$ Sum of densities of D. luteipes, N. clavipes, and O. insidiosus. ${ }^{4 /}$ Combined occurrence of Pheidole sp. and Solenopsis sp 
A total of 35.7 adults of Procornitermes sp., 7.4 Phyllophaga sp., and 7.33 larvae of Diabrotica sp. were found per $1.08 \mathrm{~m}^{3}$ of soil in all evaluations. Overall, there were 50.43 individuals of these species per $1.08 \mathrm{~m}^{3}$ of soil. Coleoptera species were abundant in the vegetative stage of $C$. juncea, and larvae of Lepidoptera in the flowering stage reached $42.88 \%$. Nematodes had greater abundance in the vegetative stage $(100 \%)$ of $C$. juncea (Table 1). Doru luteipes was found in C. juncea and superficially on the soil of crop plants without cartridge, where they feed on different prey (Fenoglio \& Trumper, 2006). This predator is common in maize and sorghum where it lay eggs and preys on the main pests, Diatraea saccharalis (Lepidoptera: Crambidae) and Spodoptera frugiperda (Lepidoptera: Noctuidae) (Figueiredo et al., 2006; Wyckhuys \& O'Neil, 2007; Lima et al., 2010). However, the higher abundance of natural enemies in organic agriculture is also due to lower levels of chemical application in these areas (Birkhofer et al., 2008; Tavares et al., 2009). Natural enemies in $C$. juncea demonstrate the importance of the culture as a refuge for insects and the need for research development on the crops, either in outline or in succession with annual or perennial crops, in order to improve the efficiency of similar agricultural regions.

The lower abundance of $M$. incognita from the flowering and pods stages of $C$. juncea suggests the allelopathic potential of this culture in these periods as recorded for this plant and/or other Fabaceae (Bhan et al., 2010), indicating that the use of these plants as organic fertilizers can reduce infestations of this species (Berry et al., 2009; McSorley et al., 2008a, 2009). The penetration of Meloidogyne sp. was above $30 \%$ in the roots of Crotalaria spectabilis (Fabaceae), but the second-stage juveniles did not reach the third stage because it was not a suitable host, although they did cause necrosis (Sano et al., 1983; Sano \& Nakasono, 1986). The incorporation of residues of Crotalaria longirostrata (Fabaceae) in the soil reduced the galls by $M$. incognita and Meloidogyne arenaria (Tylenchida: Heteroderidae) in tomato roots, due to the release of toxic compounds within plant tissue (Villar \& Zavaleta-Mejia, 1990). Plowing the soil with moldboard ploughs during crop rotation with Gossypium hirsutum (Malvaceae) and C. spectabilis or C. juncea can also reduce $M$. incognita populations and Phyllophaga sp. by exposing them to natural enemies and the allelopathic potential of these plants (McSorley et al., 2008b).

Solenopsis sp. and Pheidole sp. are widely distributed in the crops (Cassill et al., 2005; Wilkie et al., 2010). These ants may exploit food sources, present ability to recruit, and are highly aggressive (Braga et al., 2010). However, oscillations in soil temperature, prey, and soil type also create a favorable environment for ants (Varon et al., 2007). Pheidole spp. are ecologically diverse, and it also collects seeds, are omnivorous, predatory and mutualistic in associations with plants (Soares et al., 1998). The higher frequency of ants in a no-till area than in conventional crops suggests that the organic matter in this system increases the populations of Termitidae (Lange et al., 2008).

The ideal time to sow $C$. juncea in the region of Sete Lagoas, Minas Gerais State, Brazil is November and December, in succession with maize. The present study was not performed during these months, but $D$. luteipes, $N$. clavipes, and $O$. insidiosus predators were found to be the primary natural enemies in this culture. The populations of the referred predators needed to control pest populations of predatory insects in C. juncea plantations are not known, but individuals in the latter group found primarily in the soil can efficiently control insect pests.

\section{ACKNOWLEDGEMENTS}

The authors thank "Dr. Antônio Marcos Coelho" for the availability of soil analysis, "Dr. José Carlos Cruz" for the cultivation of Crotalaria juncea organic, "Dr. Rodrigo Diniz Silveira" for the identification of ants and termites, and "Dr. Sebastião Lourenço de Assis Júnior" for the identification of Coleoptera and Lepidoptera species. To "Conselho Nacional de Desenvolvimento Científico e Tecnológico (CNPq)" and "Coordenação de Aperfeiçoamento de Pessoal de Nivel Superior (CAPES)", and "Fundação de Amparo a Pesquisa do Estado de Minas Gerais (FAPEMIG)" for financial support. To "Paper Check" for editing this manuscript 
and "Mônica Ruediger de Britto Velho" for English corrections.

\section{LITERATURE CITED}

BERRY, S. D. et al. Effect of intercropping on nematodes in two small-scale sugarcane farming systems in South Africa. Nematropica, v. 39, n. 1, p. 11-33, 2009.

BHAN, M.; MCSORLEY, R.; CHASE, C. A. Effect of cropping system complexity on plant-parasitic nematodes associated with organically grown vegetables in Florida. Nematropica, v. 40, n. 1, p. 53-70, 2010.

BIRKHOFER, K. et al. Generalist predators in organically and conventionally managed grass-clover fields: implications for conservation biological control. Ann. Appl. Biol., v. 153, n. 2, p. 271-280, 2008.

BRAGA, D. L. et al. Rapid evaluation of ant diversity in land use systems in southern Bahia, Brazil. Neotrop. Entomol., v. 39, n. 4 , p. $464-469,2010$.

CASSILL, D. L. et al. Cooperation during prey digestion between workers and larvae in the ant, Pheidole spadonia. Insects Soc., v. 25, n. 4, p. 339-343, 2005.

CHELLEMI, D. O. Effect of urban plant debris and soil management practices on plant parasitic nematodes, Phytophthora blight and Pythium root rot of bell pepper. Crop Protec., v. 25, n. 10, p. 1109-1116, 2006.

ERLANDSON, L. A. W.; OBRYCKI, J. J. Predation of immature and adult Empoasca fabae (Harris) (Hemiptera: Cicadellidae) by three species of predatory insects. J. Kansas Entomol. Soc., v. 83, n. 1, p. 1-6, 2010.

FENOGLIO, M. S.; TRUMPER, E. V. Influence of weather conditions and density of Doru luteipes (Dermaptera: forficulidae) on Diatraea saccharalis (Lepidoptera: Crambidae) egg mortality. Environ. Entomol., v. 36, n. 5, p. $1159-1165,2007$.

FERRO, V. G.; GUIMARÃES JUNIOR, P. R.; TRIGO, J. R. Why do larvae of Utetheisa ornatrix penetrate and feed in pods of Crotalaria species? Larval performance vs. chemical and physical constraints. Entomol. Exp. Appl., v. 121, n. 1, p. 23-29, 2006

FIGUEIREDO, M. L. C.; MARTINS-DIAS, A. M. P.; CRUZ, I. Relationship between fall armyworm and their natural biological control agents in the maize crop. Pesq. Agropec. Bras., v. 41, n. 12, p. 1693-1698, 2006

GILL, H. K. et al. Mulch as a potential management strategy for lesser cornstalk borer, Elasmopalpus lignosellus (Insecta: Lepidoptera: Pyralidae), in bush bean (Phaseolus vulgaris).

Florida Entomol., v. 93, n. 2, p. 183-190, 2010.
GUIMARÃES, P. R. et al. Extrafloral nectaries as a deterrent mechanism against seed predators in the chemically protected weed Crotalaria pallida (Leguminosae). Austr. Ecol., v. 31, n. 6, p. 776-782, 2006.

IYENGAR, V. K.; EISNER, T. Parental body mass as a determinant of egg size and egg output in an arctiid moth (Utetheisa ornatrix). J. Insect Behavior, v. 15, n. 3, p. 309318, 2002.

JACKSON, D. M.; HARRISON, H. F. Effects of a killedcover crop mulching system on sweetpotato production, soil pests, and insect predators in South Carolina. J. Econ. Entomol., v. 101, n. 6, p. 1871-1880, 2008.

JONES, G. D.; COPPEDGE, J. R. Foraging resources of adult Mexican corn rootworm (Coleoptera: Chrysomelidae) in Bell County, Texas. J. Econ. Entomol., v. 93, n. 3, p. 636- 643, 2000 .

KOST, C.; HEIL, M. Increased availability of extrafloral nectar reduces herbivory in Lima bean plants (Phaseolus lunatus, Fabaceae). Basic Appl. Ecol., v. 6, n. 3, p. 237-248, 2005.

LANGE, D. et al. Predacious activity of ants (Hymenoptera: Formicidae) in conventional and in no-till agriculture systems Braz. Arch. Biol. Technol., v. 51, n. 6, p. 1199-1207, 2008.

LEWIS, G. P. et al. The floral scent of Cyathostegia mathewsii (Leguminosae, Papilionoideae) and preliminary observations on reproductive biology. Biochem. Syst. Ecol., v. 31, n. 9, p. 951-962, 2003.

LIMA, M. S. et al. Corn yield response to weed and fall armyworm controls. Planta Daninha, v. 28, n. 1, p. 103-111, 2010.

MCSORLEY, R.; WANG, K. W.; FREDERICK, J. J Integrated effects of solarization, sunn hemp cover crop, and amendment on nematodes, weeds, and pepper yields Nematropica, v. 38, n. 2, p. 115-125, 2008a.

MCSORLEY, R.; WANG, K. W.; CHURCH, G. Suppression of root-knot nematodes in natural and agricultural soils. Appl. Soil Ecol., v. 39, n. 3, p. 291-298, 2008 b.

MCSORLEY, R. et al. Effects of soil type and steam on nematode biological control potential of the rhizosphere community. Nematropica, v. 36, n. 2, p. 197- 214, 2006

MCSORLEY, R. et al. Non-target effects of sunn hemp and marigold cover crops on the soil invertebrate community. Nematropica, v. 39, n. 2, p. 235- 245, 2009

OLIVEIRA, L. J.; GARCIA, M. A. Flight, feeding and reproductive behavior of Phyllophaga cuyabana (Moser) (Coleoptera: Melolonthidae) adults. Pesq. Agropec. Bras. v. 38 , n. 2 , p. $179-186,2003$ 
OLIVEIRA, L. J. et al. Feeding and oviposition preference of Phyllophaga cuyabana (Moser) (Coleoptera: Melolonthidae) on several crops. Neotrop. Entomol., v. 36, n. 5, p. 759- 764, 2007.

QUEIROZ, L. R. et al. Weed suppression and organic green corn production in no tillage system. Planta Daninha, v. 28, n. 2, p. 263-270, 2010.

ROJAS-ROUSSE, D. Persistent pods of the tree Acacia caven: a natural refuge for diverse insects including Bruchid beetles and the parasitoids Trichogrammatidae, Pteromalidae and Eulophidae. J. Insect Sci., v. 8, n. 1, p. 1-9, 2006.

\section{RUSSEL, D. F. MSTAT-C Statistical Package Program} ver. 2.1. East Lansing, Michigan State University, 1989.

SANO, Z.; NAKASONO, K. Histological responses of three leguminous enemy plants to the penetration and development of Meloidogyne incognita. Jap. J. Nematol., v. 16, n. 12, p. $48-55,1986$

SANO, Z. I; NAKASONO, K.; ARAKI, M. Penetration and development of Meloidogyne incognita in some enemy and host plants. Proc. Assoc. Plant Protec. Kyushu, v. 29, n. 1, p. 132-136, 1983.

SANTOS, G. G. et al. Soil macrofauna communities and cover crops in a Cerrado Oxisol under no tillage. Pesq. Agropec. Bras., v. 43, n. 1, p. 115-122, 2008

SHARMA, A. R. et al. Moisture conservation and nitrogen recycling through legume mulching in rainfed maize (Zea mays)-wheat (Triticum aestivum) cropping system. Nutr. Cycling Agroecosyst., v. 87, n. 2, p. 187-197, 2010.

SILVA, R. F. et al. Edaphic invertebrate macrofauna in cassava cultivation under vegetable cover crops. Pesq. Agropec. Bras., v. 42, n. 6, p. 865-871, 2007.

SILVA, M. L. N. et al. Aggregates stability and resistance in Dark-Red Latosol (Oxisol) under corn green manure succession. Pesq. Agropec. Bras., v. 33, n. 1, p. 97-103, 1998.
SOARES, S. M.; MARINHO, C. G. S.; DELLA LUCIA, T. M. C. Species richness of soil ant fauna in an eucalypt plantation and a second growth forest. R. Bras. Zool., v. 15, n. 4, p. 889-898, 1998.

TAVARES, W. S. et al. Potential use of Asteraceae extracts to control Spodoptera frugiperda (Lepidoptera: Noctuidae) and selectivity to their parasitoids Trichogramma pretiosum (Hymenoptera: Trichogrammatidae) and Telenomus remus (Hymenoptera: Scelionidae). Ind. Crops Prod., v. 30, n. 3, p. 384-388, 2009.

VARON, E. H. et al. Temporal and spatial distribution of ants in a light gradient, in a coffee agroforestry system, Turrialba, Costa Rica. R. Biol. Trop., v. 55, n. 3-4, p. 943-956, 2007.

VENETTE, R. C.; MOSTAFA, F. A. M.; FERRIS, H. Trophic interactions between bacterial-feeding nematodes in plant rhizospheres and the nematophagous fungus Hirsutella rhossiliensis to suppress Heterodera schachtii. Plant Soil, v. 191, n. 2, p. 213-223, 1997.

VENZON, M. et al. Suitability of leguminous cover crop pollens as food source for the green lacewing Chrysoperla externa (Hagen) (Neuroptera: Chrysopidae). Neotrop.

Entomol., v. 35, n. 3, p. 371-376, 2006.

VILLAR, E. M. J.; ZAVALETA-MEJiA, E. Effect of Crotolaria longirostrata Hook y Arnott on root galling nematodes (Meloidogyne spp.). R. Mexicana Fitopatol., v. 8, n. 2, p. 166-172, 1990.

WANG, K. H.; SIPES, B. S.; SCHMITT, D. P. Crotalaria as a cover crop for nematode management: A review. Nematropica, v. 32, n. 1, p. 35-57, 2002.

WILKIE, K. T. R.; MERTL, A. L.; TRANIELLO, J. F. A. Species diversity and distribution patterns of the ants of Amazonian Ecuador. Plos One, v. 5, n. 10, p. 1-12, 2010.

WYCKHUYS, K. A. G; O’NEIL, R. J. Influence of extrafield characteristics to abundance of key natural enemies of Spodoptera frugiperda Smith (Lepidoptera: Noctuidae) in subsistence maize production. Inter. J. Pest Manag., v. 53, n. 2, p. $89-99,2007$ 